GOSPODARKA SUROWCAMI MINERALNYMI - MINERAL RESOURCES MANAGEMENT

2015

Volume 31

Issue 3

Pages 5-24

DOI 10.1515/gospo-2015-0026

\title{
Rewolucja lupkowa a zmiany na rynku gazu skroplonego
}

\section{Wprowadzenie}

Przyjmuje się, że w przypadku gazu ziemnego o tzw. „rewolucji łupkowej” w USA możemy mówić od 2005 r., a o rewolucji dotyczącej ropy naftowej o trzy lata później. Należy mieć na uwadze, że sukces osiągnięty w Ameryce Północnej wymagał wielu lat pracy, uporu i konsekwencji w podejmowaniu prób wdrożenia i doskonalenia technologii wydobycia. Powszechnie przyjmuje się, że ojcem tego sukcesu jest George P. Mitchell, właściciel firmy Mitchell Energy. Prace nad wypracowaniem odpowiednich technologii, które doprowadziły do rewolucji w wydobyciu gazu z Barnett Shale, trwały osiemnaście lat. Co ciekawe, postęp technologiczny w USA przełożył się na redukcję kosztów pozyskania gazu z formacji łupkowych; część gazu z formacji łupkowych może być wydobyta obecnie po niższych kosztach niż gaz ze złóż konwencjonalnych. Analiza zużycia gazu ziemnego na świecie w ciągu ostatnich lat ukazuje trend wzrostowy. Utrzymanie tego trendu w przyszłości przełoży się na wzrost znaczenia dostaw gazu w postaci LNG, a amerykański sukces związany z wydobyciem gazu ziemnego $\mathrm{z}$ łupków zmieni obecne relacje $\mathrm{w}$ międzynarodowym obrocie tym surowcem.

* Dr inż., ** Prof. dr hab. inż., AGH Akademia Górniczo-Hutnicza, Wydział Wiertnictwa, Nafty i Gazu, Kraków.

*** Dr hab. inż., AGH Akademia Górniczo-Hutnicza, Wydział Energetyki i Paliw, Kraków;

e-mail: szua@agh.edu.pl. 


\section{Zasoby gazu ziemnego}

Wielkość udokumentowanych zasobów gazu ziemnego na świecie w 2014 r. wynosiła $187,1 \mathrm{bln} \mathrm{m}^{3}$ i w porównaniu do $2000 \mathrm{r}$. wzrosła o $34 \%$. W tym samym czasie zasoby ropy naftowej wzrosły o $31 \%$, a węgla o $10 \%$, przy wzroście wydobycia gazu ziemnego, ropy naftowej oraz węgla odpowiednio o: $43 \%, 17 \%$ i $73 \%$. W konsekwencji, wskaźnik żywotności zasobów dla tych najważniejszych surowców energetycznych w analizowanym okresie zmienił się: dla gazu ziemnego - nastąpił spadek o 13\%, dla ropy naftowej - wzrost o 30\%, a dla węgla - spadek o 51\% i w 2014 r. wynosił odpowiednio: 54,1, 52,5 oraz 110 lat (BP 2015). Należy podkreślić, że od początku lat osiemdziesiątych XX wieku w USA wielkość zasobów gazu ziemnego stopniowo ulegała zmniejszeniu z poziomu $5,7 \mathrm{bln}^{3}$ (lata 1981-1983) do 4,6-4,7 bln $\mathrm{m}^{3}$ w latach dziewięćdziesiątych ubiegłego wieku, a od początku XX wieku obserwuje się stopniowy wzrost udokumentowanych zasobów węglowodorów w USA i wyraźnie odwrotną tendencję w krajach UE - tabela 1. Zasadniczy wpływ na przyrost udokumentowanych zasobów węglowodorów miała tzw. „rewolucja łupkowa”, której efekty, m.in. niskie ceny gazu ziemnego, są od kilku lat najbardziej widoczne w USA; kraju, który od 2009 r. jest liderem pod względem wielkości wydobycia gazu ziemnego.

Tabela 1. Stan zasobów udokumentowanych gazu ziemnego i ropy naftowej w USA i UE

Table 1. U.S. and EU natural gas and crude oil proved reserves

\begin{tabular}{|l|c|c|c|c|c|c|c|}
\hline \multirow{2}{*}{ Wyszczególnienie } & \multirow{2}{*}{ Jednostka } & \multicolumn{2}{|c|}{ USA } & \multicolumn{2}{c|}{ UE } & \multicolumn{2}{c|}{ Świat } \\
\cline { 3 - 8 } & & $2000 \mathrm{r}$. & $2014 \mathrm{r}$. & $2000 \mathrm{r}$. & $2014 \mathrm{r}$. & $2000 \mathrm{r}$. & $2014 \mathrm{r}$. \\
\hline Gaz ziemny & bln $\mathrm{m}^{3}$ & 5,0 & 9,8 & 3,4 & 1,5 & 139,4 & 187,1 \\
\hline Ropa naftowa & mld ton & 3,8 & 5,9 & 1,2 & 0,8 & 142,7 & 239,8 \\
\hline
\end{tabular}

Źródło: BP 2015

Z geologicznego punktu widzenia wyróżnia się następujące rodzaje niekonwencjonalnych złóż gazu (Hadro 2010): gaz z dużych głębokości (deep gas), gaz zamknięty (tight gas), gaz złupków (shalegas), metan z pokładów węgla (coal bed methane) i hydraty gazowe-rysunek 1 . Zagospodarowanie niekonwencjonalnych złóż gazu ziemnego w porównaniu do konwencjonalnych złóż charakteryzuje się m.in. zastosowaniem zaawansowanych technologii udostępnienia złóż gazu, w szczególności otworów horyzontalnych i szczelinowania hydraulicznego. Więcej na temat technologicznych aspektów eksploatacji tych złóż jest m.in. w pracach (Rychlicki i Siemek 2011; Gawlik 2013; Nagy i Siemek 2011; Michałowski i in. 2012; Kryzia i Gawlik 2012). W początkowym etapie pozyskania gazu z łupków koszty wydobycia były wysokie. Obecnie ocenia się, że jedna czwarta zasobów gazu zgromadzonego w złożach łupkowych może zostać wydobyta przy całkowitych kosztach poniżej $116 \mathrm{USD} / 1000 \mathrm{~m}^{3}$ (3 USD/MBtu) (Medlock 2012). Szerzej na temat ekonomicznych aspektów pozyskania gazu z łupków 


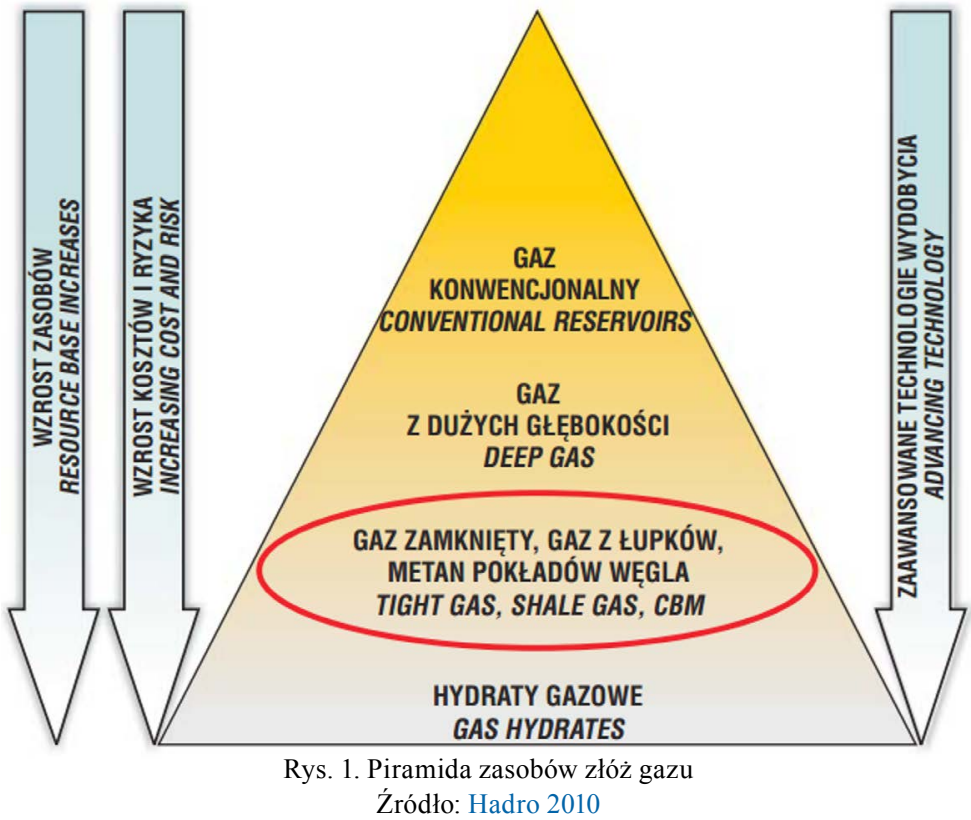

Fig. 1. Gas resource pyramid

w pracy (Kaliski i in. 2014). Warto także podkreślić, że na dzisiejszy sukces związany z wydobyciem węglowodorów w USA pewien wpływ miały także wprowadzone zmiany w prawie podatkowym, stwarzające system ulg i zachęt dla firm inwestujących w niekonwencjonalne złoża gazu ziemnego (np. Nonconventional Fuel Tax Credit) (Hadro 2010; Siemek i in. 2011).

W latach 2007-2013, dzięki rosnącemu rozpoznaniu tych złóż, odnotowano przeszło 6,5-krotny przyrost udokumentowanych zasobów gazu w formacjach łupkowych (poziom zasobów gazu w łupkach w 2013 r. wynosił 4,5 bln $\mathrm{m}^{3}$ ). Do złóż o największych zasobach gazu w łupkach zalicza się Marcellus Shale i Haynesville Shale. W tym samym czasie wydobycie gazu z łupków w USA zwiększyło się z 36,6 (2007 r.), przez 226,2 (2011 r.) do $323 \mathrm{mld} \mathrm{m}^{3}$ (2013 r.). Wydobycie gazu z łupków rosło najszybciej spośród niekonwencjonalnych złóż gazu (EIA 2014). Przewiduje się, że tendencja wzrostowa wydobycia gazu zostanie w przyszłości utrzymana (rys. 2). W latach 2013-2040 prognozuje się średnioroczny wzrost wydobycia gazu $\mathrm{z}$ łupków w scenariuszu referencyjnym na poziomie $2 \%$, przy średniorocznym wzroście wydobycia całkowitego gazu na poziomie $1,4 \%$, a w przypadku scenariusza wysokiego (High oil and gas resource), dynamika wzrostów wydobycia będzie wyższa i wynosić odpowiednio 4,2 oraz $2,8 \%$. W USA w przyszłości tempo wydobycia gazu z łupków będzie mieć kluczowe znaczenie dla wielkości całkowitego wydobycia gazu ziemnego; w 2040 r. udział wydobycia gazu z łupków będzie się kształtować w zależności od scenariusza od 55,2 do 68,3\% (EIA 2015). Zgodnie z przewidywaniami Międzynarodowej Agencji Energii (IEA - International Energy Agency) w Scenariuszu Nowych Polityk 


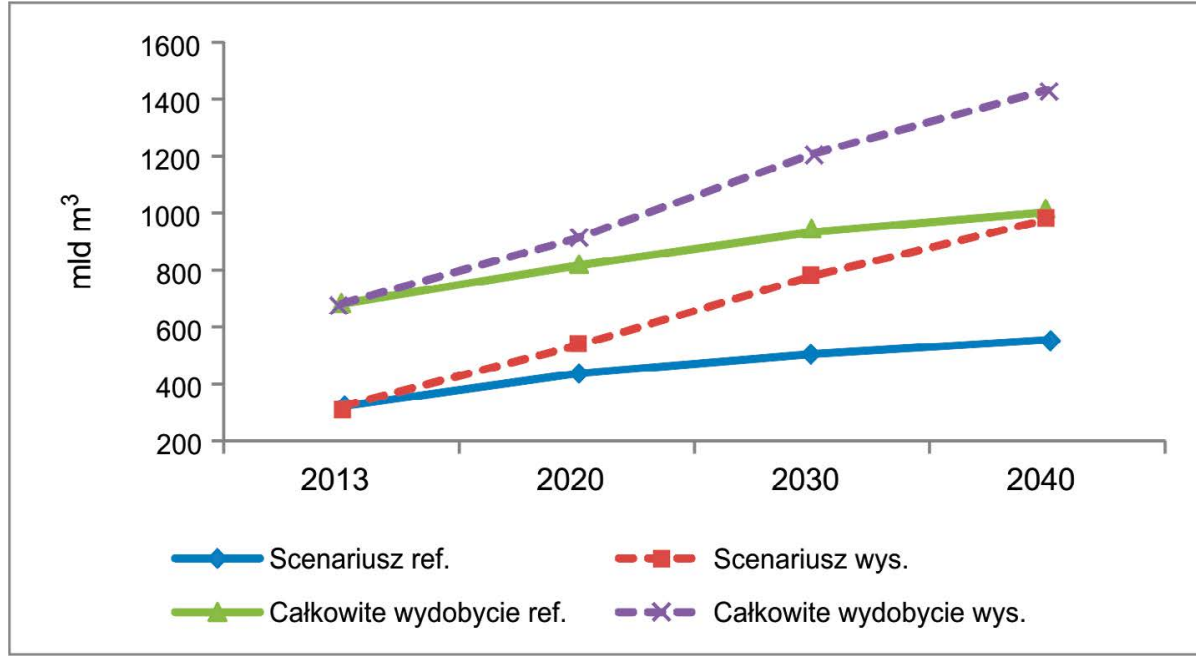

Rys. 2. Prognozy wydobycia gazu z łupków w USA [mld m³]

Źródło: opracowanie własne na podstawie EIA 2015

Fig. 2. Forecasts for shale gas production in U.S. [in bcm]

Tabela 2. Kraje o największym wydobyciu gazu ziemnego - prognoza do $2040 \mathrm{r}$. [mld $\mathrm{m}^{3}$ ]

Table 2. Countries with highest natural gas production levels - forecast to 2040 [in bcm]

\begin{tabular}{|c|c|c|c|c|}
\hline Wyszczególnienie & 2012 & 2020 & 2030 & 2040 \\
\hline USA & 507 & 817 & 897 & 923 \\
\hline Rosja & 658 & 667 & 680 & 680 \\
\hline Chiny & 107 & 171 & 266 & 368 \\
\hline Iran & 156 & 153 & 195 & 272 \\
\hline Katar & 159 & 164 & 207 & 237 \\
\hline Kanada & 156 & 168 & 192 & 233 \\
\hline Świat & 3438 & 3872 & 4626 & 5378 \\
\hline
\end{tabular}

Źródło: IEA 2014a 
USAutrzymająpozycjęliderawzakresiewydobyciagazuziemnegowperspektywiedo2040r.tabela 2. Dla Unii Europejskiej prognozy IEA nie są optymistyczne w zakresie przyszłego wydobycia gazu ziemnego - prognozuje się spadek z $174 \mathrm{mld} \mathrm{m}^{3} \mathrm{w} 2012 \mathrm{r}$. do $106 \mathrm{mld} \mathrm{m}^{3}$ w 2040 r. (IEA 2014).

Amerykański sukces zainspirował poszukiwania niekonwencjonalnych złóż gazu ziemnego $\mathrm{w}$ innych państwach, $\mathrm{w}$ tym również $\mathrm{w}$ Europie. Polska stała się jednym z najbardziej aktywnych rejonów poszukiwania tego typu złóż na starym kontynencie (Poprawa 2010). Oceniając aktywność poszukiwań za pomocą liczby zrealizowanych otworów rozpoznawczych najlepszym okresem był 2012 r., kiedy zakończono prace nad 24 otworami poszukiwawczymi gazu ziemnego z formacji łupkowych, w 2014 r. wykonano 15 otworów, a w 2015 r. jedynie 2 (do lipca). Spadek tempa prac poszukiwawczych należy wiązać m.in. z brakiem zadowalających wyników dotychczasowych prac, wycofywaniem się firm - gigantów przemysłu naftowego, takich jak ExxonMobil, ConocoPhillips czy Chevron, czy też przedłużającymi się pracami nad nowymi regulacjami prawnymi, istotnymi dla branży poszukiwawczej.

Ogółem od początku prowadzenia prac poszukiwawczych tego typu złóż wykonano w Polsce 70 otworów (MŚ 2015). Dziś już można stwierdzić, że nie spełniły się optymistyczne zapowiedzi sprzed kilku lat o rozpoczęciu przemysłowego wydobycia gazu z łupków w latach 2014-2015. Brak zadowalających rezultatów w uzyskaniu z otworu przepływu gazu, umożliwiającego przejście do etapu przemysłowego w Polsce, należy upatrywać m.in. w odmiennych uwarunkowaniach geologicznych pomiędzy formacjami łupkowymi w kraju i USA; np. zawartość materii organicznej w skale macierzystej (TOC - Total Organic Carbon), w kraju kształtuje się na poziomie od 2 do 5\%, a w USA od 2 do 14\%. Porównując głębokości zalegania złoża - wynoszą one odpowiednio 3-4 km oraz $0,4-4,6 \mathrm{~km}$ w USA, czy też skład mineralogiczny skały macierzystej, w Polsce przeważają mułowce i iłowce, które trudniej poddają się procesowi szczelinowania (PGNiG 2015). Niemniej jednak, pomimo braku zadowalających wyników prowadzących prac poszukiwawczych należy zaznaczyć, że Polska i Wielka Brytania są krajami UE najbardziej zaawansowanymi w rozpoznaniu zasobów gazu w formacjach łupkowych (Gawlik red. 2013). W przypadku Polski warto także podkreślić długoletnie badania nad innym typem niekonwencjonalnych złóż gazu - metanem z pokładów węgla (Rychlicki i Stopa 2010; Baran i in. 2014).

\section{Zmiany na globalnym rynku gazu ziemnego}

Zużycie energii pierwotnej na świecie w latach 2000-2014 wzrosło o niemal 38\%. Wzrost $\mathrm{w}$ tym czasie zużycia energii pierwotnej przedstawiał się następująco: rejon Azji i Pacyfiku - wzrost o 103\%, Środkowego Wschodu - o 96\%, Afryki - o 53\%, Ameryki Centralnej i Południowej - o 48\%, Ameryki Północnej - o 2,3\%, Europy i Eurazji - wzrost o $0,3 \%$. Należy zaznaczyć, że wzrost zużycia energii pierwotnej wśród państw 
zrzeszonych w OECD wyniósł tylko 1\%, natomiast wśród państw spoza OECD wyniósł ponad $89 \%$. Na uwagę zasługuje fakt, że w analizowanym okresie tylko w krajach UE odnotowano spadek zużycia energii o ponad 7\%; wpływ na to miał kryzys gospodarczy, który rozpoczął się w USA w 2008 r. i swym zasięgiem objął także kraje europejskie (BP 2015). Zapotrzebowanie na energię pierwotną pokrywane jest głównie przez kopalne nośniki energii, gdzie gaz ziemny jest jednym z kluczowych surowców wykorzystywanych do tego celu. W 2014 roku światowe zapotrzebowanie na energię pierwotną pokryte zostało przez: ropę naftową - 4211 Mtoe (32,6\% zapotrzebowania); węgiel - 3882 Mtoe (30\% zapotrzebowania); gaz ziemny - 3066 Mtoe (23,7\% zapotrzebowania); energię jądrową - 574 Mtoe (4,4\% zapotrzebowania) i OZE - 1196 Mtoe (9,3\% zapotrzebowania) W przypadku gazu ziemnego, w stosunku do roku 2000 odnotowano wzrost zużycia na poziomie $42 \%$. Analizując udział gazu w bilansie energetycznym w 2014 r. w poszczególnych regionach świata sytuacja wygląda następująco: Ameryka Północna - 30,7\%; Ameryka Centralna i Południowa - 22,1\%; Europa i Eurazja - 32,1\%; Środkowy Wschód 50,6\%; Afryka - 25,7\%; Azja i Pacyfik - 11,4\%. Największy wzrost zużycia gazu w analizowanym okresie miał miejsce w rejonie Środkowego Wschodu - 141\% oraz Azji i Pacyfiku - $133 \%$. Analizując zużycie gazu w wybranych państwach należy zaznaczyć, że największym konsumentem tego surowca są Stany Zjednoczone, które w 2014 roku zużywały go 695,3 Mtoe, co stanowiło wzrost o ponad 19\% w stosunku do roku 2000. Pomimo tego, że wzrost zużycia gazu w Stanach Zjednoczonych nie jest największy wśród analizowanych państw, na uwagę zasługuje fakt, że pokrycie tego wzrostu nastąpiło w wyniku zwiększenia krajowego wydobycia (BP 2015). W tabeli 3 przedstawiono, jak kształtował się udział gazu ziemnego w strukturze zużycia energii pierwotnej w wybranych państwach.

Analiza danych z tabeli 3 pokazuje, że w większości państw UE w ciągu ostatnich lat zmniejszyła się rola gazu ziemnego w strukturze zużycia energii pierwotnej. Istotny wpływ na tę tendencję miał spadek wykorzystania paliw gazowych w celach energetycznych. W UE widoczny jest - w większości przypadków - systematyczny wzrost znaczenia udziału OZE w strukturze wytwarzania energii elektrycznej, kosztem m.in. wykorzystania gazu ziemnego - tabela 4. W przypadku USA tempo wzrostu wykorzystania OZE jest mniejsze niż w UE; na rynku amerykańskim obserwuje się umocnienie pozycji gazu ziemnego w produkcji energii elektrycznej, głównie kosztem węgla kamiennego, co pociąga za sobą problemy dla górnictwa węgla kamiennego - w sierpniu $2015 \mathrm{r}$. bankructwo ogłosił drugi największy producent węgla w USA - Alpha Natural Resources.

Analizując spadek wykorzystania gazu ziemnego w sektorze energetycznym w krajach UE w latach 2008-2014 największy miał miejsce we Włoszech - 16,6; Hiszpanii - 11,6 i Wielkiej Brytanii - 10,6 mld $\mathrm{m}^{3}$ (EC 2015). Szerzej zmiany w strukturze wytwarzania energii elektrycznej w Wielkiej Brytanii, w której gaz ziemny przestał być już paliwem o najważniejszym znaczeniu, przedstawiono w publikacji (Olkuski 2014). 
Tabela 3. Udział gazu ziemnego w strukturze zużycia energii pierwotnej w wybranych państwach w latach 2000-2014 [\%]

Table 3. Share of natural gas in primary energy consumption in selected countries in 2000-2014 [\%]

\begin{tabular}{|c|c|c|c|c|c|c|c|c|}
\hline Państwo & 2000 & 2002 & 2004 & 2006 & 2008 & 2010 & 2012 & 2014 \\
\hline Stany Zjednoczone & 25,5 & 25,9 & 24,8 & 24,1 & 26,1 & 26,8 & 29,8 & 30,2 \\
\hline Kanada & 24,5 & 26,6 & 26,8 & 27,2 & 27,3 & 27,1 & 27,6 & 28,2 \\
\hline Austria & 21,0 & 22,1 & 25,2 & 25,5 & 25,9 & 26,8 & 23,0 & 21,5 \\
\hline Belgia & 20,2 & 20,6 & 21,0 & 20,8 & 21,4 & 25,6 & 25,3 & 23,0 \\
\hline Dania & 23,4 & 25,0 & 25,7 & 23,5 & 24,0 & 23,0 & 20,4 & 16,5 \\
\hline Finlandia & 13,1 & 13,5 & 13,6 & 13,8 & 13,3 & 12,3 & 10,4 & 8,4 \\
\hline Francja & 14,0 & 14,6 & 15,2 & 15,2 & 15,4 & 16,8 & 15,5 & 13,6 \\
\hline Niemcy & 21,6 & 22,5 & 23,4 & 23,8 & 23,7 & 23,3 & 22,2 & 20,5 \\
\hline Grecja & 5,3 & 5,5 & 6,5 & 8,4 & 10,9 & 10,4 & 12,5 & 9,4 \\
\hline Węgry & 41,7 & 45,7 & 49,2 & 45,1 & 43,7 & 41,9 & 41,9 & 37,7 \\
\hline Irlandia & 24,5 & 25,5 & 24,7 & 25,8 & 29,7 & 32,6 & 30,6 & 27,1 \\
\hline Włochy & 33,1 & 33,4 & 35,9 & 38,0 & 39,6 & 39,5 & 37,9 & 34,3 \\
\hline Litwa & 35,7 & 30,2 & 30,4 & 36,0 & 33,7 & 46,2 & 48,7 & 42,5 \\
\hline Holandia & 40,8 & 40,1 & 39,7 & 37,2 & 38,0 & 39,0 & 37,1 & 35,6 \\
\hline Polska & 11,3 & 11,6 & 13,0 & 13,1 & 12,8 & 14,0 & 15,1 & 15,3 \\
\hline Rumunia & 41,6 & 40,2 & 40,3 & 40,3 & 34,6 & 35,8 & 35,5 & 31,4 \\
\hline Federacja Rosyjska & 53,0 & 54,1 & 53,9 & 56,6 & 55,2 & 55,7 & 53,6 & 54,0 \\
\hline Hiszpania & 11,8 & 14,0 & 17,0 & 20,6 & 24,4 & 20,9 & 20,0 & 17,8 \\
\hline Szwecja & 1,4 & 1,4 & 1,4 & 1,8 & 1,8 & 2,8 & 1,8 & 1,6 \\
\hline Turcja & 17,2 & 21,8 & 23,3 & 28,3 & 31,6 & 32,3 & 33,2 & 34,9 \\
\hline Ukraina & 46,5 & 47,2 & 46,9 & 43,6 & 40,9 & 38,8 & 36,3 & 34,6 \\
\hline Wielka Brytania & 38,9 & 38,5 & 38,5 & 36,1 & 39,9 & 40,5 & 32,9 & 31,9 \\
\hline Iran & 49,3 & 56,1 & 49,9 & 54,5 & 55,1 & 58,4 & 60,9 & 60,8 \\
\hline Kuwejt & 45,3 & 38,7 & 38,7 & 45,4 & 43,0 & 40,7 & 43,1 & 44,9 \\
\hline Arabia Saudyjska & 41,8 & 44,6 & 41,4 & 41,7 & 40,3 & 39,0 & 40,5 & 40,7 \\
\hline Australia & 17,7 & 19,5 & 19,4 & 17,4 & 17,9 & 20,1 & 14,2 & 21,4 \\
\hline Chiny & 2,7 & 2,6 & 2,5 & 2,9 & 3,6 & 4,0 & 4,8 & 5,6 \\
\hline Indie & 7,5 & 7,6 & 7,8 & 8,9 & 8,6 & 10,7 & 9,2 & 7,1 \\
\hline Indonezja & 29,3 & 29,8 & 29,6 & 28,2 & 27,5 & 24,4 & 20,0 & 19,8 \\
\hline Japonia & 13,3 & 12,8 & 13,6 & 14,4 & 16,6 & 16,9 & 22,0 & 22,2 \\
\hline Pakistan & 40,4 & 42,1 & 48,6 & 48,5 & 50,8 & 52,6 & 53,7 & 51,4 \\
\hline Korea Południowa & 9,9 & 11,3 & 13,1 & 14,1 & 14,9 & 15,1 & 16,7 & 15,7 \\
\hline
\end{tabular}

Źródło: opracowanie własne na podstawie: BP 2015, IEA 2014b 
Tabela 4. Znaczenie gazu ziemnego i OZE w strukturze wytwarzania energii elektrycznej w wybranych państwach [\%]

Table 4. Importance of natural gas and RES in electricity production in selected countries [\%]

\begin{tabular}{|c|c|c|c|c|c|c|}
\hline Państwo & Udział [\%] & 2000 & 2010 & 2012 & 2013 & 2014 \\
\hline \multirow{2}{*}{ Węgry } & Gazu ziemnego & 18,8 & 31,0 & 27,2 & 18,3 & 14,4 \\
\hline & OZE & 0,7 & 8,1 & 7,6 & 9,2 & 10,6 \\
\hline \multirow{2}{*}{ Dania } & Gazu ziemnego & 24,3 & 20,3 & 13,7 & 9,8 & 6,9 \\
\hline & OZE & 15,5 & 31,2 & 48,3 & 46,0 & 56,2 \\
\hline \multirow{2}{*}{ Holandia } & Gazu ziemnego & 57,5 & 62,8 & 54,4 & 54,7 & 49,2 \\
\hline & OZE & 3,3 & 9,5 & 12,2 & 12,1 & 11,4 \\
\hline \multirow{2}{*}{ Hiszpania } & Gazu ziemnego & 9,1 & 31,8 & 24,9 & 20,4 & 17,2 \\
\hline & OZE & 15,6 & 32,8 & 29,6 & 38,9 & 40,1 \\
\hline \multirow{2}{*}{ Kanada } & Gazu ziemnego & 5,5 & 8,6 & 11,0 & 10,3 & 10,3 \\
\hline & OZE & 60,6 & 61,7 & 62,8 & 62,8 & 61,9 \\
\hline \multirow{2}{*}{ Niemcy } & Gazu ziemnego & 9,2 & 14,4 & 12,4 & 11,0 & 10,0 \\
\hline & OZE & 6,2 & 16,7 & 23,0 & 24,3 & 26,2 \\
\hline \multirow{2}{*}{ Irlandia } & Gazu ziemnego & 39,1 & 62,3 & 50,2 & 49,1 & 49,7 \\
\hline & OZE & 5,0 & 13,1 & 19,2 & 21,7 & 24,4 \\
\hline \multirow{2}{*}{ Polska } & Gazu ziemnego & 0,7 & 3,1 & 3,9 & 3,2 & 3,3 \\
\hline & OZE & 1,6 & 6,9 & 10,4 & 10,4 & 12,5 \\
\hline \multirow{2}{*}{$\begin{array}{c}\text { Wielka } \\
\text { Brytania }\end{array}$} & Gazu ziemnego & 39,6 & 46,4 & 27,8 & 26,8 & 30,4 \\
\hline & OZE & 2,7 & 6,8 & 11,4 & 15,1 & 19,4 \\
\hline \multirow{2}{*}{ USA } & Gazu ziemnego & 15,8 & 23,4 & 29,6 & 27,0 & 26,8 \\
\hline & OZE & 8,2 & 10,1 & 12,0 & 12,6 & 12,9 \\
\hline
\end{tabular}

Źródło: opracowanie własne na podstawie danych IEA 2015a

\section{Charakterystyka rynku LNG}

Wraz ze wzrostem wykorzystania gazu ziemnego w światowej gospodarce następuje na wzór rynku ropy naftowej - globalizacja rynku gazu ziemnego. Jednym z kluczowych czynników rozwoju globalnego rynku gazu ziemnego jest wzrost wykorzystania technologii skraplania tego paliwa. Na rysunku 3 przedstawiono udział skroplonego gazu ziemnego w światowym handlu tym surowcem. Z przedstawionych informacji wynika, że od roku 2001 systematycznie wzrasta rola LNG w światowym handlu gazem ziemnym. W roku 2001 stosunek przesyłanego gazu ziemnego przy użyciu gazociągów do gazu ziemnego przewożo- 
nego w formie LNG wynosił ponad 2,87, a w 2014 r. - 1,99. W analizowanych czternastu latach, wielkość handlu gazem ziemnym w formie skroplonej wzrastała średniorocznie o 9,5\%, co stanowi ponad dwukrotnie więcej niż w przypadku gazu przesyłanego gazociągami (4,5\%). Wraz ze wzrostem ilości gazu ziemnego przewożonego w formie LNG wzrastają także zdolności skraplające oraz regazyfikacyjne. Na rysunku 3 przedstawiono zestawienie możliwości skraplających i regazyfikacyjnych od 2001 do 2013 roku. Na uwage zasługuje fakt, że możliwości regazyfikacyjne znacznie przekraczają możliwości skraplające. W roku 2001 stosunek możliwości regazyfikacyjnych do możliwości skraplających wynosił 2,14, a w 2013 r. $-2,46$.

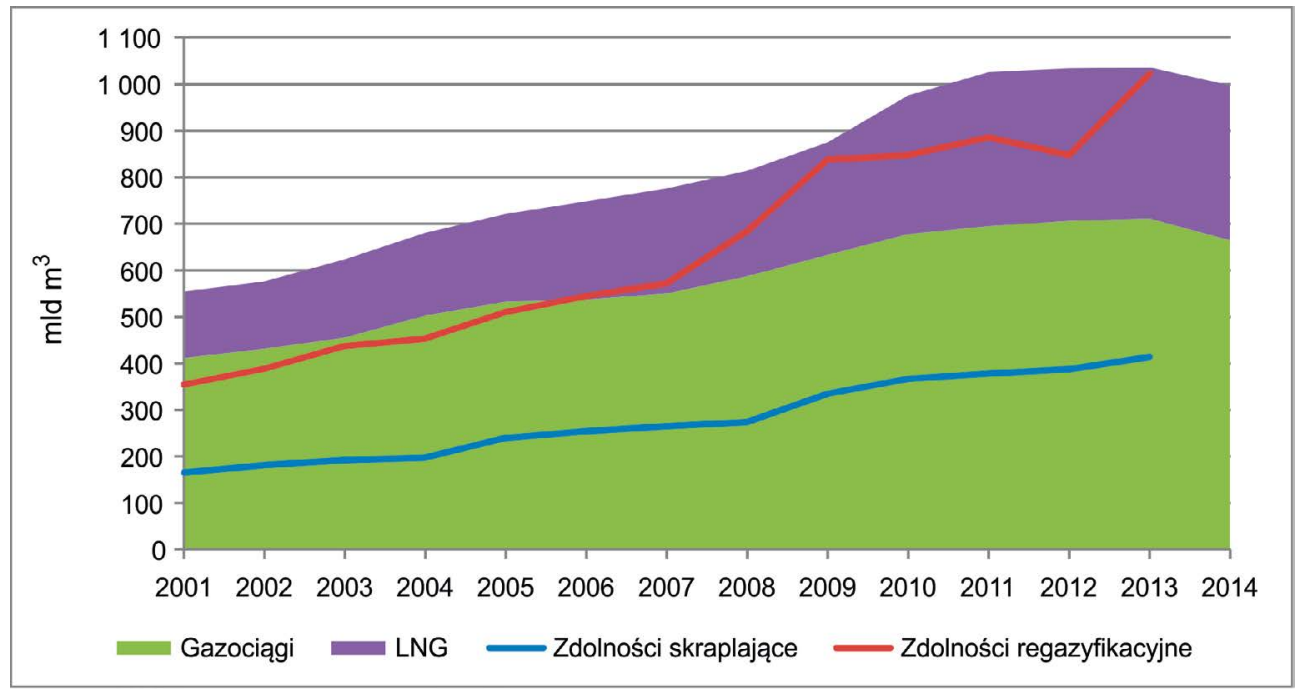

Rys. 3. Udział skroplonego gazu ziemnego w światowym handlu gazem oraz zestawienie możliwości skraplających i regazyfikacyjnych terminali LNG Źródło: opracowanie własne na podstawie BP 2015, IEA 2014b

Fig. 3. Share of LNG in global gas trade and the summary of regasification and liquefaction capacities of LNG terminals

W tabeli 5 przedstawiono rozwój mocy terminali regazyfikacyjnych od 2001 do 2013 roku. W tym czasie możliwości regazyfikacyjne wzrosły ponad 2,8 razy, wzrost ten wynosił średniorocznie $22 \%$. Na uwagę zasługuje fakt, że wśród państw, które posiadają terminale regazyfikacyjne są też kraje, posiadające jednocześnie terminale skraplające - tj. Indonezja, Malezja i USA. Zgodnie z informacjami IEA w 2015 roku zostaną oddane do użytku terminale regazyfikacyjne o łącznej mocy regazyfikacyjnej $44,5 \mathrm{mld} \mathrm{m}^{3} \mathrm{w}$ następujących państwach: Chile - 1,7; Chiny - 8,5; Francja - 13; Indonezja - 4,1 (jednostka FSRU - Floating, Storage and Regasification Unit); Japonia - 1,4; Jordania - 4,8 (jednostka FSRU); Pakistan - 2,0 (jednostka FSRU); Filipiny - 4,1 i Polska - $5 \mathrm{mld} \mathrm{m}^{3}$. Natomiast w roku 2017 całkowite możliwości regazyfikacyjne powinny wynosić około $1100 \mathrm{mld} \mathrm{m}^{3}$ (IEA 2015b). 
14

Janusz, Kaliski i Szurlej 2015 / Gospodarka Surowcami Mineralnymi - Mineral Resources Management 31(3), 5-24

Tabela. 5. Zestawienie możliwości regazyfikacyjnych wybranych państw w latach 2001-2013 [mld $\mathrm{m}^{3}$ ]

Table 5. Regasification capacities of individual countries in 2001-2013 [bcm]

\begin{tabular}{|c|c|c|c|c|c|c|c|c|c|c|c|c|c|}
\hline Państwo & 2001 & 2002 & 2003 & 2004 & 2005 & 2006 & 2007 & 2008 & 2009 & 2010 & 2011 & 2012 & 2013 \\
\hline Argentyna & 0 & 0 & 0 & 0 & 0 & 0 & 0 & 0 & 3,2 & 3,2 & 9,7 & 10,8 & 10,8 \\
\hline Belgia & 5,3 & 5,3 & 5,3 & 5,5 & 5,5 & 5,5 & 5,5 & 9,5 & 9,5 & 9,5 & 9,5 & 9,5 & 9,5 \\
\hline Brazylia & 0 & 0 & 0 & 0 & 0 & 0 & 0 & 0 & 7,9 & 7,9 & 7,9 & 7,9 & 13,4 \\
\hline Kanada & 0 & 0 & 0 & 0 & 0 & 0 & 0 & 0 & 10,6 & 10,6 & 10,6 & 10,6 & 10,6 \\
\hline Chile & 0 & 0 & 0 & 0 & 0 & 0 & 0 & 0 & 3,9 & 6 & 6 & 6 & 6 \\
\hline Chiny & 6,3 & 6,3 & 24,3 & 24,3 & 24,3 & 29,5 & 29,5 & 42,9 & 44,5 & 47,2 & 40,9 & 47,4 & 66,4 \\
\hline Dominikana & 0 & 0 & 2,5 & 2,4 & 2,4 & 2,4 & 2,4 & 2,4 & 2,4 & 2,4 & 2,4 & 2,4 & 2,4 \\
\hline Dubaj & 0 & 0 & 0 & 0 & 0 & 0 & 0 & 0 & 0 & 3,2 & 3,2 & 4,3 & 5,2 \\
\hline Francja & 15,3 & 15,3 & 17,3 & 16,4 & 18 & 18 & 18 & 18 & 26,7 & 25,1 & 25,1 & 25,1 & 25,2 \\
\hline Grecja & 2,2 & 2,2 & 2,2 & 2,5 & 1,4 & 1,4 & 1,4 & 1,4 & 5,3 & 5,6 & 5,3 & 5,3 & 5,3 \\
\hline Indie & 0 & 0 & 0 & 0 & 11,1 & 10,9 & 11 & 11 & 16,8 & 16,8 & 16,8 & 18,4 & 29,9 \\
\hline Indonezja & 0 & 0 & 0 & 0 & 0 & 0 & 0 & 0 & 0 & 0 & 0 & 0 & 5,3 \\
\hline Włochy & 3,7 & 3,7 & 3,5 & 3,5 & 3,5 & 3,5 & 3,5 & 3,5 & 11,9 & 11,9 & 11,9 & 11,9 & 16,2 \\
\hline Izrael & 0 & 0 & 0 & 0 & 0 & 0 & 0 & 0 & 0 & 0 & 0 & 0 & 5,1 \\
\hline Japonia & 233 & 241,1 & 242,9 & 240,7 & 232,9 & 251,4 & 254,7 & 252,6 & 263,4 & 264,2 & 252,2 & 274,4 & 275 \\
\hline Korea & 49,9 & 69,1 & 69,3 & 79,3 & 103,6 & 84,8 & 101,2 & 107,6 & 110 & 110 & 124,6 & 128 & 130,2 \\
\hline Kuwejt & 0 & 0 & 0 & 0 & 0 & 0 & 0 & 0 & 7,5 & 7,5 & 7,5 & 5,5 & 5,5 \\
\hline Malezja & 0 & 0 & 0 & 0 & 0 & 0 & 0 & 0 & 0 & 0 & 0 & 0 & 5,5 \\
\hline Meksyk & 0 & 0 & 0 & 0 & 0 & 5,6 & 7,1 & 19,1 & 19,1 & 19,1 & 18,7 & 24,6 & 24,6 \\
\hline Holandia & 0 & 0 & 0 & 0 & 0 & 0 & 0 & 0 & 0 & 0 & 9,4 & 12,7 & 12,7 \\
\hline Portugalia & 0 & 0 & 5,8 & 5,5 & 5,5 & 5,5 & 5,5 & 5,5 & 5,5 & 5,5 & 8 & 8 & 8 \\
\hline Puerto Rico & 4 & 4 & 4 & 4 & 4 & 4 & 4 & 4 & 4 & 4 & 4 & 4 & 4 \\
\hline Singapur & 0 & 0 & 0 & 0 & 0 & 0 & 0 & 0 & 0 & 0 & 0 & 0 & 8,2 \\
\hline Hiszpania & 16,1 & 18,3 & 27,1 & 31,2 & 39,3 & 52,2 & 57,4 & 60,5 & 63,2 & 63,2 & 63,4 & 63,3 & 63,3 \\
\hline Tajlandia & 0 & 0 & 0 & 0 & 0 & 0 & 0 & 0 & 0 & 0 & 6,9 & 6,9 & 7,7 \\
\hline Turcja & 1,7 & 6,5 & 6,3 & 6,5 & 6,5 & 12,8 & 12,8 & 12,8 & 12,8 & 12,8 & 12,8 & 12,8 & 12,8 \\
\hline Wielka Brytania & 0 & 0 & 0 & 0 & 4,9 & 4,9 & 4,9 & 19,1 & 47,6 & 54 & 54 & 54,7 & 56,4 \\
\hline USA & 16,5 & 16,5 & 26,6 & 31,1 & 47,2 & 51,9 & 53,3 & 114,1 & 162,5 & 158 & 174,8 & 193,2 & 196,6 \\
\hline Suma & 354 & 388,3 & 437,1 & 452,9 & 510,1 & 544,3 & 572,2 & 684 & 838,3 & 847,7 & 885,6 & 947,7 & 1021,8 \\
\hline
\end{tabular}

Źródło: opracowanie własne na podstawie IEA 2014b 
Analizując możliwości regazyfikacyjne posiadane przez poszczególne państwa należy zwrócić uwagę na stopień wykorzystania terminali - rysunek 4 . $Z$ analizy przedstawionych danych wynika, że wykorzystanie terminali regazyfikacyjnych wynosi średnio $31 \%$. Maksymalne wykorzystanie terminali miało miejsce w Chinach i wyniosło $60 \%$. Natomiast w Japonii - kraju posiadającym $27 \%$ całkowitych możliwości regazyfikacyjnych - ich wykorzystanie w 2013 roku wyniosło tylko 45\%. Niektóre kraje, takie jak Indonezja, Malezja, Izrael, pomimo że posiadają zdolności regazyfikacyjne do roku 2013 ich nie wykorzystywały.

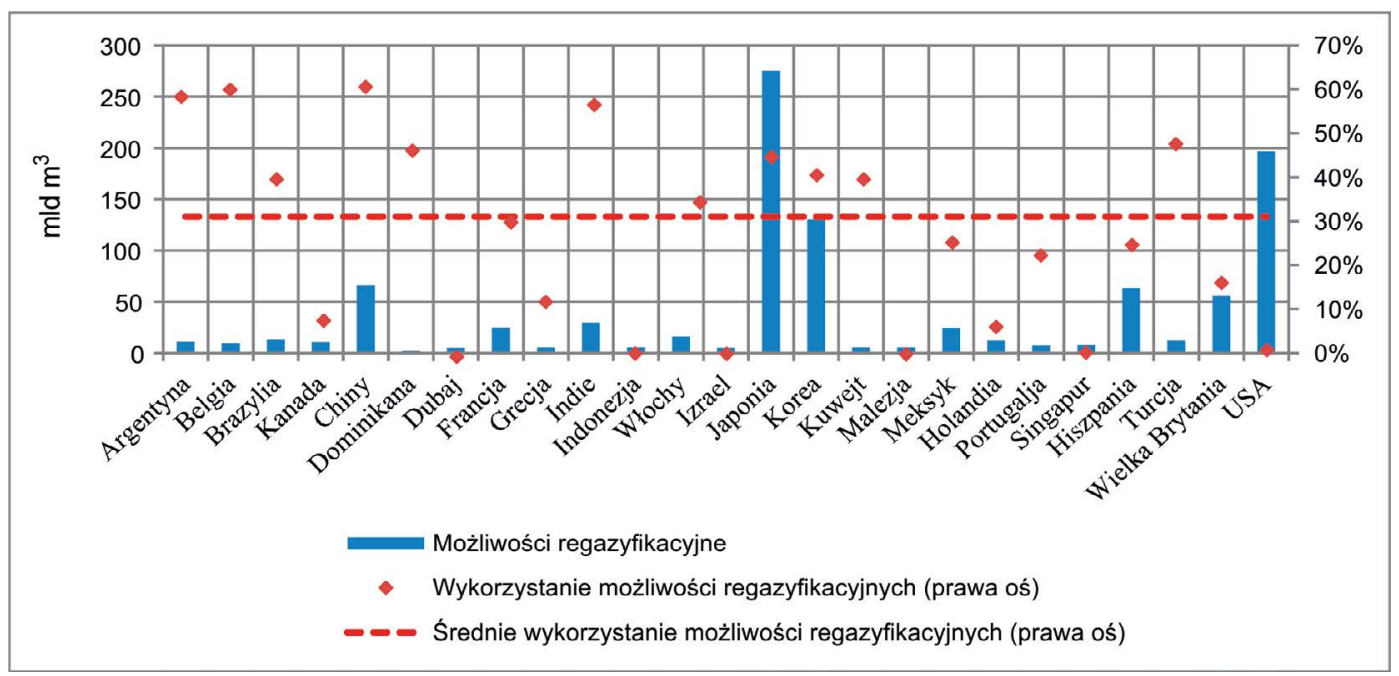

Rys. 4. Wykorzystanie możliwości regazyfikacyjnych przez wybrane państwa w 2013 r. Źródło: opracowanie własne na podstawie: IEA 2014b

Fig. 4. Use of regasification capacities by selected countries in 2013

W tabeli 6 przedstawiono rozwój możliwości skraplających od 2001 do 2013 roku. W tym czasie możliwości skraplające wzrosły 2,5-krotnie, a średnioroczny wzrost wyniósł $19 \%$. Ponadto obecnie w trakcie budowy są instalacje skraplające o łącznej możliwości skraplającej 174,6 $\mathrm{mld} \mathrm{m}^{3}$, w takich państwach jak: Indonezja $-5,4 \mathrm{mld} \mathrm{m}^{3}$; Kolumbia $-0,7 \mathrm{mld} \mathrm{m}^{3}$; Malezja $-8,6 \mathrm{mld} \mathrm{m}^{3}$; Australia $-71,6 \mathrm{mld} \mathrm{m}^{3}$; Stany Zjednoczone $-65,9 \mathrm{mld} \mathrm{m}^{3}$; Federacja Rosyjska $-22,4 \mathrm{mld} \mathrm{m}^{3}$. Oddanie tych instalacji do użytkowania powinno nastąpić do 2019 roku (IEA 2015b). Kolejną istotną informacją dotyczącą terminali skraplających jest stopień ich wykorzystania, który w 2013 roku wynosił średnio 75\% (rys. 5). LNG ogrywa coraz większą rolę także w UE. Tabela 7 przedstawia najważniejsze dane dotyczące roli dostaw gazu skroplonego do państw UE. Jak widać w ciągu ostatnich lat można zauważyć zmniejszenie roli tych dostaw. Mając na uwadze niski obecnie stopień wykorzystania zdolności importowych terminali LNG w UE, można zauważyć istniejący w tym zakresie potencjał (Ruszel 2014).

Zapewne wpływ na ten spadek zapotrzebowania na LNG ma zmniejszenie zużycia gazu ziemnego w UE o $109 \mathrm{mld} \mathrm{m}^{3}$ latach 2008-2014, co odpowiada 22\% redukcji zużycia. 
Wraz ze wzrostem wydobycia gazu ze złóż niekonwencjonalnych w Stanach Zjednoczonych nastąpiły znaczące zmiany cen tego surowca. W tabeli 8 przedstawiono zmiany cen gazu ziemnego na rynku amerykański (Henry Hub), japońskim (LNG w Japonii) oraz europejskim: na rynku brytyjskim - najpłynniejszym hubie (National Balancing Point - NBP), na którym ceny odzwierciedlają rynkową grę popytu i podaży oraz niemieckim (cena importu gazu na granicy).

Tabela 6. Zestawienie możliwości skraplających posiadanych przez poszczególne państwa w latach 2001-2013 [ $\mathrm{mld} \mathrm{m}^{3}$ ]

Table 6. Liquefaction capacities of individual countries in 2001-2013 [bcm]

\begin{tabular}{|c|c|c|c|c|c|c|c|c|c|c|c|c|c|}
\hline Państwo & 2001 & 2002 & 2003 & 2004 & 2005 & 2006 & 2007 & 2008 & 2009 & 2010 & 2011 & 2012 & 2013 \\
\hline Australia & 10,3 & 10,3 & 10,2 & 16 & 16 & 27,3 & 27,3 & 25,5 & 25,6 & 26,9 & 26,9 & 32,7 & 32,7 \\
\hline Angola & 0 & 0 & 0 & 0 & 0 & 0 & 0 & 0 & 0 & 0 & 0 & 0 & 7,1 \\
\hline Abu Dabi & 7,4 & 7,4 & 0 & 0 & 0 & 0 & 0 & 0 & 0 & 0 & 0 & 0 & 0 \\
\hline Algieria & 31,6 & 31,6 & 34,9 & 26,8 & 27,7 & 27,7 & 27,7 & 27,6 & 27,6 & 27,6 & 26,3 & 26,4 & 26,4 \\
\hline Brunei & 9,2 & 9,2 & 9,8 & 9,8 & 9,8 & 9,8 & 9,8 & 9,8 & 9,8 & 9,8 & 9,8 & 9,7 & 9,7 \\
\hline Egipt & 0 & 0 & 0 & 0 & 16,4 & 16,6 & 16,6 & 16,6 & 16,6 & 16,6 & 16,6 & 16,6 & 16,6 \\
\hline $\begin{array}{l}\text { Gwinea } \\
\text { Równikowa }\end{array}$ & 0 & 0 & 0 & 0 & 0 & 0 & 5 & 5 & 5 & 5 & 5 & 5 & 5 \\
\hline Indonezja & 42,3 & 46,8 & 39,4 & 39,6 & 39,6 & 36,8 & 36,8 & 36,7 & 47 & 47 & 47 & 46,3 & 46,3 \\
\hline Libia & 3,6 & 3,6 & 0,8 & 0,8 & 0,8 & 0,8 & 0,8 & 0,8 & 0,8 & 0,8 & 0,8 & 4,4 & 4,4 \\
\hline Malezja & 21 & 21 & 30,3 & 30,3 & 30,3 & 31 & 31 & 30,8 & 30,8 & 30,8 & 32,8 & 32,8 & 32,8 \\
\hline Nigeria & 8 & 12,2 & 13,1 & 13,8 & 19 & 24,2 & 24,2 & 29,5 & 29,5 & 29,5 & 29,56 & 29,6 & 29,6 \\
\hline Norwegia & 0 & 0 & 0 & 0 & 0 & 0 & 5,8 & 5,4 & 5,8 & 5,8 & 5,8 & 5,8 & 5,8 \\
\hline Oman & 9 & 9 & 10 & 9,6 & 14,7 & 15 & 15 & 14,6 & 14,6 & 14,6 & 14,6 & 14,6 & 14,6 \\
\hline Peru & 0 & 0 & 0 & 0 & 0 & 0 & 0 & 0 & 0 & 6,1 & 6,1 & 6,1 & 6,1 \\
\hline Katar & 16,9 & 19,4 & 20,3 & 27,4 & 35,3 & 35,3 & 35,3 & 41,7 & 73,5 & 94,1 & 104,7 & 104,7 & 104,7 \\
\hline Federacja Rosyjska & 0 & 0 & 0 & 0 & 0 & 0 & 0 & 0 & 13 & 13 & 13 & 13 & 13 \\
\hline Trinidad i Tobago & 3,9 & 8,7 & 13,5 & 13,9 & 20,2 & 20,2 & 20,2 & 20,5 & 20,5 & 20,5 & 20,5 & 21,1 & 42,2 \\
\hline $\begin{array}{l}\text { Zjednoczone } \\
\text { Emiraty Arabskie }\end{array}$ & 0 & 0 & 7,8 & 7,6 & 7,6 & 7,6 & 7,6 & 7,6 & 7,6 & 7,6 & 7,6 & 7,9 & 7,9 \\
\hline USA & 1,8 & 1,8 & 1,9 & 1,9 & 1,9 & 1,9 & 1,9 & 1,9 & 1,9 & 1,9 & 1,9 & 1,9 & 0 \\
\hline Jemen & 0 & 0 & 0 & 0 & 0 & 0 & 0 & 0 & 4,6 & 9,1 & 9,1 & 9,1 & 9,1 \\
\hline Suma & 165 & 181 & 192 & 197,5 & 239,3 & 254,2 & 265 & 274 & 334,2 & 366,7 & 378 & 387,7 & 414 \\
\hline
\end{tabular}

Źródło: opracowanie własne na podstawie: IEA 2014b 


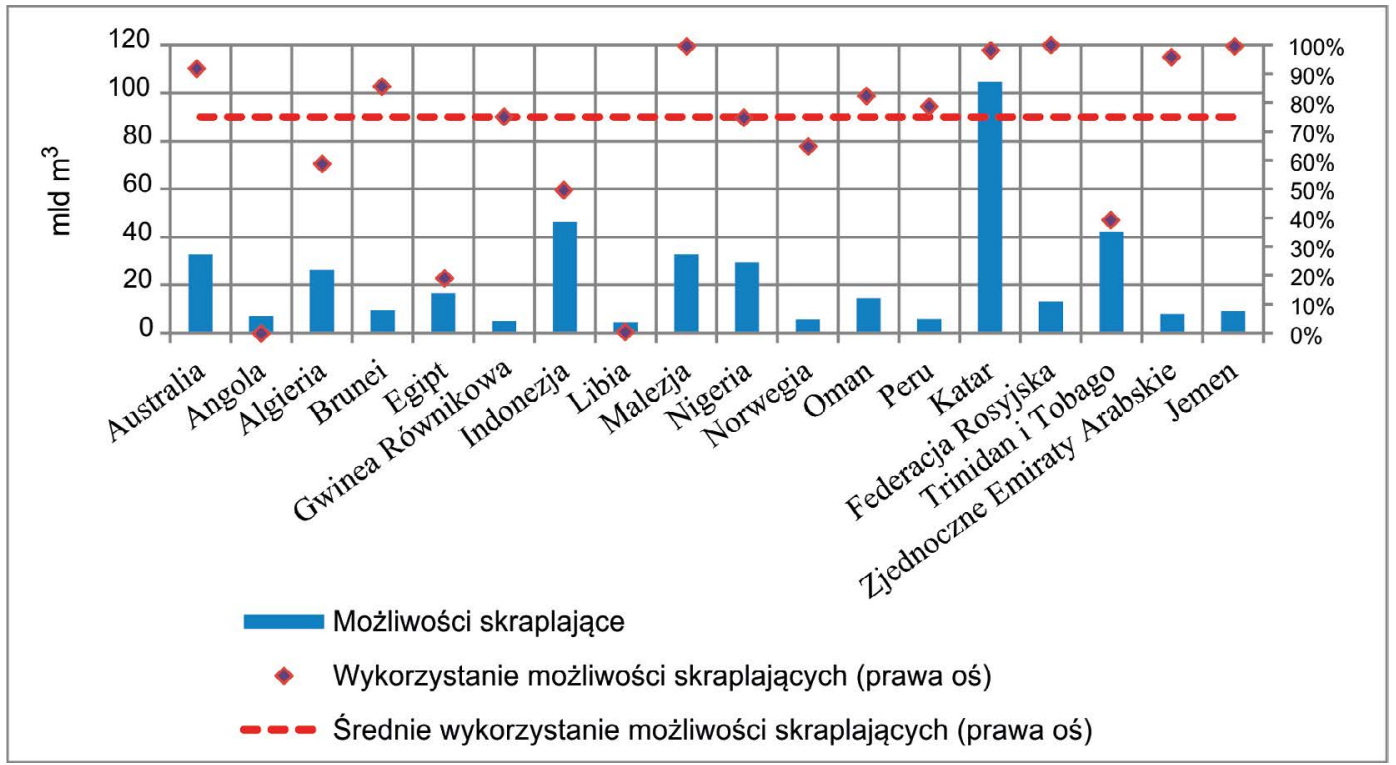

Rys. 5. Wykorzystanie możliwości skraplających przez poszczególne państwa w 2013 r. Źródło: opracowanie własne na podstawie IEA IEA 2014b

Fig. 5. Use of liquefaction capacities by individual countries in 2013

Tabela 7. Znaczenie dostaw LNG dla zbilansowania zapotrzebowania na gaz UE

Table 7. Importance of LNG supply in balancing the EU's demand for gas

\begin{tabular}{|l|c|c|c|c|c|c|c|}
\hline \multicolumn{1}{|c|}{ Wyszczególnienie } & Jedn. & 2008 & 2009 & 2010 & 2011 & 2012 & 2013 \\
\hline Wielkość dostaw LNG & mld m ${ }^{3}$ & 51,0 & 61,6 & 81,1 & 74,8 & 58,3 & 41,3 \\
\hline Wielkość dostaw LNG & TWh & 552,8 & 667,1 & 878,2 & 810,3 & 631,3 & 447 \\
\hline Udział dostaw LNG & $\%$ & 13 & 19 & 25 & 24 & 19 & 14 \\
\hline Najwięksi dostawcy & - & $\begin{array}{c}\text { Algieria, } \\
\text { Nigeria, } \\
\text { Katar }\end{array}$ & $\begin{array}{c}\text { Algieria, } \\
\text { Katar, } \\
\text { Nigeria }\end{array}$ & $\begin{array}{c}\text { Katar, } \\
\text { Nigeria, } \\
\text { Algieria }\end{array}$ & $\begin{array}{c}\text { Katar, } \\
\text { Nigeria, } \\
\text { Algieria }\end{array}$ & $\begin{array}{c}\text { Katar, } \\
\text { Algieria, } \\
\text { Algia }\end{array}$ & $\begin{array}{c}\text { Katgieria, } \\
\text { Nigeria }\end{array}$ \\
\hline
\end{tabular}

Źródło: opracowanie własne na podstawie danych Eurogas 2009-2014

Analiza kosztów importu gazu ziemnego do Polski w latach 2002-2013 wskazuje, że koszty te wzrosły przeszło 4,5-krotnie i wyniosły na koniec analizowanego okresu 4,03 mld EURO, przy czym głównym powodem tego poważnego wzrostu nie było istotne zwiększenie wolumenu import gazu (wzrost o 50\%), a wzrost z tytułu ceny jednostkowej gazu ze $112 \mathrm{EUR} / 1000 \mathrm{~m}^{3}$ (2004 r.) do $391 \mathrm{EUR} / 1000 \mathrm{~m}^{3}$ (MG 2014). Mając na uwadze, 
Tabela 8. Ceny gazu ziemnego w wybranych hub ach gazowych w latach 2005-2014 [USD/1000 $\mathrm{m}^{3}$ ]

Table 8. Natural gas prices in selected gas hubs in 2005-2014 [USD/1000 m³

\begin{tabular}{|l|c|c|c|c|c|c|c|c|c|c|}
\hline Wyszczególnienie & 2005 & 2006 & 2007 & 2008 & 2009 & 2010 & 2011 & 2012 & 2013 & 2014 \\
\hline Henry Hub & 343,55 & 262,32 & 271,26 & 344,32 & 153,51 & 170,61 & 155,45 & 106,87 & 144,96 & 170,61 \\
\hline NBP & 285,64 & 296,91 & 234,34 & 417,38 & 185,37 & 254,94 & 350,54 & 368,42 & 413,50 & 320,62 \\
\hline Granica niemiecka & 226,57 & 306,24 & 310,90 & 451,19 & 331,50 & 312,07 & 412,72 & 430,99 & 417,00 & 354,04 \\
\hline LNG w Japonii & 233,95 & 276,70 & 300,80 & 492,00 & 351,32 & 423,60 & 574,39 & 649,00 & 623,74 & 631,52 \\
\hline
\end{tabular}

Źródło: IEA 2015b

że inwestycja w terminal LNG w Polsce była rozważana praktycznie już od lat dziewięćdziesiątych ubiegłego wieku (Piwowarski i Trzop 2009; Wiśniewski 2005), w artykule przeprowadzono analizę jak kształtowałyby się wydatki związane z importem gazu ziemnego, przy założeniu rozpoczęcia importu LNG od 2009 r. Szczegółowe założenia, niezbędne do oszacowania hipotetycznych wydatków importowych zakupu gazu, z uwzględnieniem importu LNG oraz wyniki obliczeń przedstawiono na rysunku 6 oraz w tabeli 9.

Dla wyznaczenia hipotetycznych wydatków importowych związanych z zakupem gazu ziemnego założono, że wielkość dostaw LNG od 2009 r. (wiersz 4 w tabeli 9) jest różnicą pomiędzy rzeczywistym wolumenem importu gazu (wiersz 1) a dostawami gazu z kierunku wschodniego (wiersz 3), na podstawie aneksu do porozumienia międzyrządowego

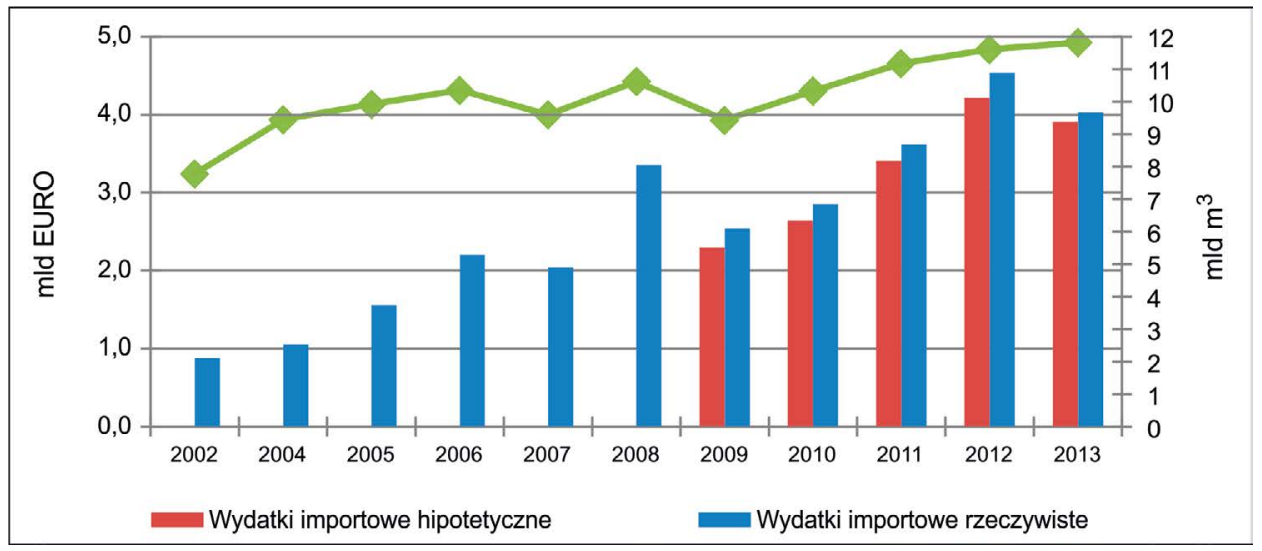

Rys. 6. Analiza kosztów importu gazu ziemnego w latach 2002-2013 Źródło: opracowanie własne na podstawie MG 2014

Fig. 6. Analysis of the cost of natural gas imports in 2002-2013 
Tabela 9. Założenia i wyniki obliczeń hipotetycznych wydatków importu gazu ziemnego do Polski

Table 9. Assumptions and results of hypothetical calculations of the cost of importing natural gas to Poland

\begin{tabular}{|c|c|c|c|c|c|c|c|}
\hline Lp. & Wyszczególnienie & Jednostka & 2009 & 2010 & 2011 & 2012 & 2013 \\
\hline 1. & Wolumen importu & mld $\mathrm{m}^{3}$ & 9,435 & 10,325 & 11,174 & 11,605 & 11,818 \\
\hline 2. & Jamał_2003 [GOST] & $\operatorname{mld~} \mathrm{m}^{3}$ & 7,3 & 8 & 8 & 8 & 8 \\
\hline 3. & Jamał_2003 [PN] & $\operatorname{mld~} \mathrm{m}^{3}$ & 6,80 & 7,45 & 7,45 & 7,45 & 7,45 \\
\hline 4. & Dostawy alternatywne (LNG) & $\mathrm{mld} \mathrm{m}^{3}$ & 2,63 & 2,87 & 3,72 & 4,15 & 4,36 \\
\hline 5. & Cena jedn. (rzeczywista) & $\mathrm{EUR} / 1000 \mathrm{~m}^{3}$ & 269 & 276 & 324 & 391 & 341 \\
\hline 6. & Wartość dostaw Jamał_2003 & mld EUR & 1,829 & 2,057 & 2,415 & 2,914 & 2,542 \\
\hline 7. & Kurs wymiany USD/PLN & PLN & 3,116 & 3,016 & 2,963 & 3,2570 & 3,1608 \\
\hline 8. & Kurs wymiany EUR/PLN & PLN & 4,327 & 3,995 & 4,120 & 4,1850 & 4,1975 \\
\hline 9. & Ceny LNG do UE & USD/MBtu & 6,240 & 6,850 & 9,450 & 10,260 & 10,600 \\
\hline 10. & Ceny LNG do UE & $\mathrm{EUR} / 1000 \mathrm{~m}^{3}$ & 176,357 & 202,958 & 266,776 & 313,379 & 313,266 \\
\hline 11. & Wartość dostaw (LNG) & mld EUR & 0,464 & 0,583 & 0,993 & 1,301 & 1,367 \\
\hline 12. & Rzeczywiste wydatki importowe & mld EUR & 2,538 & 2,85 & 3,62 & 4,538 & 4,03 \\
\hline 13. & Hipotetyczne wydatki importowe & mld EUR & 2,294 & 2,640 & 3,407 & 4,215 & 3,909 \\
\hline 14. & Różnice w wydatkach & mld EUR & 0,244 & 0,210 & 0,213 & 0,323 & 0,121 \\
\hline 15. & Różnice w wydatkach & mld PLN & 1,056 & 0,839 & 0,876 & 1,350 & 0,508 \\
\hline
\end{tabular}

Źródło: opracowanie własne na podstawie MG 2014; NBP; IEA 2014b

z 2003 r. (Szurlej 2013) (wiersz 2). Założono, że ceny LNG to średnie ceny LNG w dostawach do UE, zgodnie z (IEA 2014b) (wiersz 9), które przeliczono na EUR/1000 m³ (wykorzystano ciepło spalania LNG z Kataru - 41,4 MJ/m³ , dlatego że Katar jest największym dostawcą LNG do krajów UE i będzie także czołowym dostawcą LNG na rynek krajowy wiersz 10).

Analizując rzeczywiste (wiersz 12) i hipotetyczne (wiersz 13) wydatki importowe można zauważyć, że zakładając rozpoczęcie realizacji dostaw LNG do Polski od 2009 r., miałoby to przełożenie na zmniejszenie całkowitych kosztów importu gazu ziemnego w latach 2009-2013 - przy założeniach zawartych w tabeli 9 - o 1,11 mld Euro (4,629 mld PLN). Jest to pokaźna kwota, przewyższająca całkowite nakłady inwestycyjne budowanego terminala LNG w Świnoujściu, które wynoszą 3,04 mld PLN (GAZ-SYSTEM 2015). Wydatki importowe związane z zakupem gazu ziemnego w przyszłości będą uzależnione od kształtowania się cen w kontraktach długoterminowych i na rynku spot. Nie ulega wątpliwości, że posiadanie terminala LNG będzie ważnym atutem w prowadzonych negocjacjach cenowych 
dotyczących kontraktów długoterminowych. Obecnie oczekuje się, że zwiększona podaż gaz ziemnego w Ameryce Północnej przełoży się import tego surowca do krajów UE i w ten sposób obniży się cena gazu na rynku europejskim. Oczywiście, w poszczególnych latach ceny LNG w krajach UE zmieniały się i zauważyć można także znaczne różnice w zależności od kraju - dostawcy LNG; przykładowo, analizując dostawy LNG do Wielkiej Brytanii w 2013 r., ceny LNG z Norwegii to 328,34 USD/1000 m³ (10,25 USD/MBtu), a z Trynidadu - 250,66 USD/1000 m³ (6,45 USD/MBtu) (IEA 2014b). Rozważając przyszły import LNG z USA należy zaznaczyć - mając na uwadze obecnie obowiązujące procedury w zakresie uzyskiwania zgody na eksport gazu z USA - że nie sposób określić precyzyjnie jego wpływu na europejski rynek gazu; będzie to uzależnione od wyników negocjowanej umowy handlowej pomiędzy USA i UE (The Transatlantic Trade and Investment Partnership - TTIP). Ponadto rozważając import LNG z Ameryki do Europy warto także zwrócić uwagę na łączne koszty dostaw (koszty skraplania, transportu gazowcami, regazyfikacji i przesyłu gazociągami łączącymi instalacje z miejscem wydobycia), kształtujące się od 125 do $220 \mathrm{USD} / 1000 \mathrm{~m}^{3}$; w większości opracowań koszty te wynoszą poniżej $175 \mathrm{USD} / 1000 \mathrm{~m}^{3}$ (Garbicz i Sokół 2013). Analizując możliwości obniżenia cen gazu ziemnego, nie bez znaczenia jest $\mathrm{w}$ tym kontekście również dalsza liberalizacja rynków paliw i energii (Kamiński 2009, 2014; Gross-Gołacka i in. 2013).

\section{Podsumowanie}

Zmiany związane z pozyskaniem gazu ziemnego (i ropy naftowej) ze złóż niekonwencjonalnych w Ameryce Północnej nie ograniczają się jedynie do wpływu na strukturę pozyskania energii pierwotnej na kontynencie amerykańskim, ale mają istotny wpływ na inne rynki energii, w tym na tendencje dotyczące międzynarodowego obrotu węglowodorami. Jest to zrozumiałe, bowiem amerykański rynek gazu ziemnego od wielu lat jest największym pod względem konsumpcji gazu, od 2009 r. jest także największym pod względem wydobycia gazu. Kluczową rolę w umocnieniu pozycji USA w rankingu wydobycia węglowodorów odegrała tzw. rewolucja łupkowa. Dzięki niej od 2009 r. obserwuje się wyraźne zróżnicowanie kształtowania się cen gazu ziemnego na rynku amerykańskim oraz europejskim w 2014 r. europejskie ceny gazu były około dwukrotnie wyższe od cen w USA. Te istotne różnice w cenach gazu ziemnego mają zasadniczy wpływ z jednej strony na umocnienie się pozycji gazu ziemnego $\mathrm{w}$ bilansie energii pierwotnej USA, w tym roli gazu w wytwarzaniu energii elektrycznej, z drugiej zaś na spadek znaczenia gazu w strukturze energii pierwotnej UE. Spostrzeżenie to nie dotyczy Polski, w której znaczenie gazu ziemnego rośnie w bilansie energii pierwotnej i zapewne ten wzrost zostanie utrzymany mając na uwadze realizowane inwestycje w bloki gazowo-parowe (Szurlej i in. 2014). Jak wynika z prognoz przybliżonych w artykule utrzymanie wzrostu wydobycia gazu ze złóż niekonwencjonalnych w USA nie tylko umocni pozycję lidera tego państwa w rankingu krajów o największym wydobyciu, ale także zapewni Stanom Zjednoczonym status eksportera netto gazu ziemnego. Dalsze 
inwestycje infrastrukturalne $\mathrm{w}$ rozbudowę mocy terminali skraplających przełożą się na awans USA do ścisłej czołówki państw będących eksporterami LNG. Zgodnie z prognozami IEA do 2020 roku Stany Zjednoczone będą należeć do ścisłej czołówki państw posiadających największe możliwości skraplające - około $80 \mathrm{mld} \mathrm{m}$ 3/rok (IEA 2015b). Zapewne przyszłymi odbiorcami tego gazu będą dzisiejszy najwięksi importerzy LNG, a więc rynek azjatycki i europejski. Jak wynika $\mathrm{z}$ analizy przeprowadzonej w artykule, zakładając realizację dostaw LNG do Polski w latach 2009-2013, miałoby to przełożenie na ograniczenie wydatków importowych związanych z zakupem gazu ziemnego na kwotę 4,63 mld zł.

Praca sfinansowana z badań statutowych AGH nr 11.11.210.217.

\section{LITERATURA}

Baran i in. 2014 - Baran, P., Rogozińska, J., Zarębska, K. i Porada, S. 2014. Analiza układu węgiel kamiennygaz pod kątem intensyfikacji wydobycia metanu z użyciem ditlenku węgla. Przemyst Chemiczny 93, 12, s. 2008-2012.

BP 2015. BP Statistical Review of World Energy, June [Online] Dostępne w: www.bp.com [Dostęp: 29.07.2015]. Eurogas 2009-2014. Statistical Report 2009-2014. Brussels; www.eurogas.org/ [Dostęp: 29.07.2015].

EC 2015. European Commission, Directorate-General for Energy. Market Observatory for Energy, Quarterly Report, Volume 7 (issue 4; fourth quarter of 2014)

EIA 2014. Natural Gas. Shale gas, December 4; [Online] Dostępne w: www.eia.gov/naturalgas/ [Dostęp: 29.07.2015]

EIA 2015. Annual Energy Outlook 2015 With Projections to 2040. April; [Online] Dostępne w: www.eia.gov/forecasts/aeo [Dostęp: 29.07.2015].

Gawlik, L. 2013. Gaz ziemny z lupków w Polsce - raport. Polski Komitet Światowej Rady Energetycznej. Wyd. IGSMiE, Warszawa; www.wec-pksre/publikacje.html (Shale gas in Poland).

Gawlik, L. (red.) 2013. Węiel dla polskiej energetyki w perspektywie 2050 roku-analizy scenariuszowe. Górnicza Izba Przemysłowo-Handlowa, Wyd. Instytutu GSMiE PAN, Katowice, 299 s.

GAZ-SYSTEM 2015. Strona internetowa Operatora Gazociagów Przesyłowych GAZ-SYSTEM [Online] Dostępne w: http://www.gaz-system.pl/terminal-lng/finansowanie/ [Dostęp: 29.07.2015].

Garbicz, M. i Sokół, H. 2013. Czy gaz łupkowy zmieni polską sytuację? Rynek Energii 6, s. 13-18.

Gross-Gołacka i in. 2013 - Gross-Gołacka, E., Lubiewa-Wieleżyński, W., Sikora, A.P., Szurlej, A. i Biały, R. 2013. Wyzwania dla producentów nawozów mineralnych w kontekście liberalizacji krajowego rynku gazu ziemnego. Przemyst Chemiczny 92, 8 1393-1398.

Hadro, J. 2010. Strategia poszukiwań złóż gazu ziemnego w łupkach. Przegląd Geologiczny 58, 3, s. $250-258$.

IEA 2014a - International Energy Agency 2014. World Energy Outlook. Paris, France.

IEA 2014b - International Energy Agency. Natural Gas Information 2000-2014, Paris, France.

IEA 2015a - International Energy Agency 2015. Energy Balances of OECD Countries. Paris., France.

IEA 2015b - International Energy Agency 2015. Gas Medium Term Market Report 2015.

Kaliski i in. 2014 - Kaliski, M., Krupa, M., Sikora, A. i Szurlej, A. 2014. Ekonomiczne aspekty pozyskiwania gazu z formacji łupkowych na podstawie doświadczeń rynku północnoamerykańskiego. Rynek Energii 1, s. $151-158$.

Kamiński, J. 2009. The impact of liberalisation of the electricity market on the hard coal mining sector in Poland. Energy Policy 37, 3, s. 925-939.

Kamiński, J., 2014. A blocked takeover in the Polish power sector: A model-based analysis. Energy Policy 66 March, s. $42-52$.

Kryzia, D. i Gawlik, L. 2012. Perspektywy gazu z łupków w Polsce. Zeszyty Naukowe Instytutu Gospodarki Surowcami Mineralnymi i Energia PAN 82, s. 5-20. 
Medlock, K.B. 2012. Shale Gas, Emerging Fundamentals, and Geopolitics. Presentation at James A Baker III Institute for Public Policy, Rice University, June 14.

Michałowski i in. 2012 - Michałowski, M., Tora, B., Čablík, V. i Černotová, L. 2012. Wybrane problemy wydobycia gazu łupkowego. Rocznik Ochrona Środowiska - Annual Set The Environment Protection t. 14, s. 866-874.

MG 2014. Ministerstwo Gospodarki 2014. Polska 2014. Raport o stanie handlu zagranicznego. Warszawa; [Online] Dostępne w: www.mg.gov.pl [Dostęp: 2.08.2015]

MŚ 2015. Ministerstwo Środowiska 2015; [Online] Dostępne w: http://lupki.mos.gov.pl/ [Dostęp: 30.07.2015].

Nagy, S. i Siemek, J. 2011. Shale Gas in Europe: the State of the Technology - challenges and opportunities. Archives of Mining Sciences 56, 4, s. 727-760.

NBP 2015 - Narodowy Bank Polski 2015 - Kursy średnie walut obcych w złotych (Tabela A); www.nbp.pl [Dostęp: 3.08.2015].

Olkuski, T. 2014. Udział gazu w strukturze produkcji energii elektrycznej w Wielkiej Brytanii w latach 2000-2012. Rynek Energii 3, s. 14-19.

PGNiG 2015. Raport roczny 2014. Warszawa; [Online] Dostępne w: www.pgnig.pl [Dostęp: 29.07.2015].

Piwowarski, A. i Trzop S. 2009 Uwarunkowania techniczno-ekonomiczne funkcjonowania krajowego terminalu LNG. Top Consulting Conference \& Trainings, 16-17 listopada 2009 Countryard by Marriott Hotel, Warszawa.

Poprawa, P. 2010. System węglowodorowy z gazem ziemnym w łupkach - północnoamerykańskie doświadczenia i europejskie perspektywy. Przegląd Geologiczny 58, 3, s. 216-225.

Ruszel, M. 2014. Znaczenie terminali LNG na wspólnym rynku energii UE. Polityka i Społeczeństwo nr 4, s. 49-59.

Rychlicki, S. i Siemek, J. 2011. Gaz łupkowy - zasoby i technologia. Rynek Energii 3, s. 3-8.

Rychlicki, S. i Stopa, J. M. 2010. Niekonwencjonalne złoża gazu ziemnego szansą dla Polski. Profesjonalne Gazownictwo 2010, Wyd. AKNET-Press, s. 21-26.

Siemek i in. 2011 - Siemek, J., Kaliski, M., Janusz, P., Sikora, S. i Szurlej, A. 2011. Wpływ shale gas na rynek gazu ziemnego w Polsce. Rynek Energii 5, s. 118-124.

Szurlej, A. 2013. The state policy for natural gas sector. Arch. Min. Sci. 58, 3, s. 925-940.

Szurlej i in. 2014 - Szurlej, A., Kamiński, J., Janusz, P., Iwicki, K. i Mirowski, T., 2014. Rozwój energetyki gazowej a bezpieczeństwo energetyczne. Rynek Energii 6, s. 33-38.

Wiśniewski, F. 2005. Terminale LNG na polskim wybrzeżu. Rurociagi 4/41, s. 33-35.

\title{
REWOLUCJA LUPKOWA A ZMIANY NA RYNKU GAZU SKROPLONEGO
}

\author{
Słowa kluczowe \\ gaz ziemny, gaz skroplony (LNG), gaz z łupków, import, eksport, \\ bezpieczeństwo energetyczne
}

\section{Streszczenie}

Sukces w zakresie zagospodarowania niekonwencjonalnych złóż gazu ziemnego, a szczególnie gazu z formacji łupkowych - tzw. rewolucja łupkowa - jest najbardziej widoczny w Ameryce Północnej. Sukces ten był możliwy dzięki zaangażowania firm, jednostek naukowych, a także wsparciu ze strony rządu amerykańskiego poprzez stworzenie systemu ulg i zachęt dla firm inwestujących w niekonwencjonalne złoża gazu ziemnego (Nonconventional Fuel Tax Credit). Prace nad doborem odpowiednich technologii (odwierty horyzontalne oraz szczelinowanie hydrauliczne), które doprowadziły do rewolucji w wydobyciu gazu ze złoża Barnett Shale, trwały 18 lat. Rewolucja łupkowa odmieniła niekorzystną, spadkową tendencję wydobycia gazu ziemnego w USA. Dzięki systematycz- 
nemu wzrostowi wydobycia gazu ziemnego, USA od 2009 r. są na pierwszym miejscu pod względem wydobycia gazu na świecie, praktycznie są już samowystarczalne, a w niedalekiej przyszłości będą eksporterem netto gazu ziemnego. Gaz ten w formie skroplonej trafi na europejskie rynki w 2016 r.; strona polska oczekuje, że import gazu ziemnego z USA umożliwi obniżkę cen na krajowym rynku gazu ziemnego. Mając na uwadze obecnie obowiązujące procedury w zakresie uzyskiwania zgody na eksport gazu, dużą wagę przywiązuje się do negocjowanej umowy handlowej pomiędzy USA i UE (The Transatlantic Trade and Investment Partnership - TTIP). W artykule przybliżono wydatki importowe związane z zakupem gazu ziemnego w latach 2002-2013. Oszacowano wpływ importu LNG na wydatki związane z importem gazu ziemnego poprzez zaproponowanie hipotetycznego scenariusza dostaw gazu ziemnego do Polski, uwzględniającego dostawy LNG od 2009 r. W artykule przeanalizowano zmiany w zakresie zużycia energii pierwotnej w latach 2000-2014. Największy wzrost odnotowano w rejonie Azji i Pacyfiku - 103\% i Środkowego Wschodu - 96\%, w przypadku rejonu Ameryki Północnej - 2,3\%, zaś w UE - spadek ponad 7\%. Mając na uwadze, że jednym z głównych kierunków wykorzystania gazu ziemnego jest jego zużycie na cele energetyczne, oceniono jak zmieniało się wykorzystanie gazu oraz OZE w energetyce w latach 2000-2014 w wybranych krajach świata. W artykule przedstawiono zmianę zdolności regazyfikacyjnych terminali importowych LNG oraz zdolności skraplających terminali eksportowych LNG oraz stopnień ich wykorzystania od 2000 do 2014 roku. Ponadto przedstawiono udział skroplonego gazu ziemnego w imporcie gazu ziemnego do krajów UE. Artykuł kończy się podsumowaniem, w którym zawarto główne wnioski.

\section{THE ‘SHALE GAS REVOLUTION' AND CHANGES ON THE LNG MARKET}

$$
\text { Keywords }
$$

natural gas, LNG, shale gas, import, export, energy security

Abstract

Success in developing unconventional natural gas deposits, and in particular shale gas deposits, the so-called shale gas revolution, is most apparent in North America. This success was made possible because of the involvement of companies, scientific bodies, as well as because of the support of American government by setting up a system of tax breaks and incentives for companies investing in non conventional natural gas deposits (Non-Conventional Fuel Tax Credit). The process of developing appropriate technologies (horizontal drilling and hydraulic fracturing) that led to the revolution in producing gas from the Barnett Shale, took 18 years. The shale gas revolution has changed the undesirable and downward trend in producing natural gas in the US. By steadily increasing the production of natural gas, the United States have been ranked first, since 2009, in terms of the production of gas worldwide. They are practically self sufficient now, and in the near future they will be a net exporter of natural gas. The gas, in liquefied form, will be supplied to the European markets in 2016. Poland expects that the imports of natural gas from the US will possibly drive down the prices on the domestic natural gas market. Taking into account the current procedures for obtaining the consent for exportation of the gas, great importance is attached to the Transatlantic Trade and Investment Partnership - TTIP). The article presents importation expenses relating to natural gas purchase in the years 
2002-2013. The impact of LNG imports on the expenses for natural gas imports has been estimated through a proposal of a hypothetical scenario of natural gas supplies to Poland, including the supply of LNG since 2009. The article analyses the changes in primary energy consumption in the years 2000-2014. The highest rate of increase has been seen in Asia and Pacific: 103\%, and the Middle East: 96\%. In the case of North America it has been 2.3\%, and in EU a decrease of more than $7 \%$ has been shown. Considering that one of the main uses of natural gas is its consumption for energy producing purposes, the article estimates how the use of natural gas and RES has changed in the energy sector in the years 2000-2014, in selected countries worldwide. The article shows changes to regasification capacities of LNG import terminals, and liquefaction capacities of LNG export terminals, and their rate of utilisation in the years 2000-2014. Moreover, the article presents the share of liquefied natural gas in the importation of natural gas in EU countries. The paper closes with a summary where the main conclusions have been reached. 